\title{
Developing Module on Constructivist Learning Strategies to Promote Students' Independence and Performance
}

\author{
Rufii Rufii ${ }^{1, *}$ \\ ${ }^{1}$ Dept.of Educational Technology, Post-Graduate Program, PGRI Adi Buana University, Jalan \\ Dukuh Menanggal XII-4, Surabaya 60234, Indonesia \\ *Correspondence: PGRI Adi Buana University, Jalan Dukuh Menanggal XII-4, Surabaya \\ 60234, Indonesia. Tel: 62-813-3217-1971 E-mail: rufiiunipa1@gmail.com
}

Received: November 24, 2014 Accepted: January 9, 2015 Published: January 21, 2015

doi:10.5296/ije.v7i1.6675 URL: http://dx.doi.org/10.5296/ije.v7i1.6675

\begin{abstract}
Constructivist learning strategies addresses learner's characteristics in addition to learner's active participation and connection to his or her knowledge and experience in learning process. The use of learning module supports the learning. The present article was to describe the development of learning module on the basis of constructivist learning theories for the Research Methodology course of the Elementary School Teacher Education Department. It includes (a) the description of the earlier teacher-centered learning in the course, (b) analysis of student and lecturer needs, (c) analysis of student characteristics, (d) identification of common goals, (e) identification of specific learning purposes, (f) development of constructivist learning strategies, and $(\mathrm{g})$ development of prototype products. The data collection techniques used in this study included: (a) document studies, (b) questionnaire, and (c) observation. The collected data were then analyzed using descriptive statistics for quantitative and qualitative data. The result revealed that the use of the constructivist learning strategies, and the learning module became a necessity. The module to be developed included: (a) lecturer's guidance, (b) learning module, (c) students' worksheet. The content was illustrated in the prototype products.
\end{abstract}

Keywords: module, research methodology course, constructivist, students' independence, performance 


\section{Introduction}

Learning Research Methodology is in general still dependent on lecturers or often called the traditional learning approach. It is teacher-centered and causes learners' passive acceptance of knowledge and information. Consequently, it can lead to various problems such as: (a) lecturers are too dominating most of the learning activities and (b) learning acquisition can be very limited due to much reliance on information by lecturers (Mahony, 2003). Applying the traditional approach to learning is not necessarily wrong. But ideally a good learning process puts a lecturer as a learning manager. In this instance, he or she does not merely transmit knowledge to learners, but he or she arrange and leads them to attain successful learning, for instance by motivating them to be responsible for meeting their own needs, being knowledgeable of learners' individual characteristics and all methods of teaching, believing in their ability, willing to take risks, and acting as a facilitator and resource person.

Kemp (1985) has stated that the design of the learning will be more effective if more attention is given to individual learners than to the group as a whole. A print module can be designed to be used for that purpose. According to Winkel (1991), the module can be used to study independently or individually because the module contains objectives, instruction sheet, reading materials, answer keys, and evaluation tools. Modules can be used as an alternative form of presentation of materials used in learning, including learning Research Methodology.

A learning module is a self-contained, formally structured learning experience with a coherent and explicit set of learning outcomes and assessment criteria. Referring to the constructivist learning strategy, the module can aid learners construct what they learn and understand, and facilitate their active participation in the process. The module can be in form of and can be learned on one's own. It also has a specific theme and is 'self contained' and 'self-directed'. It provides students with information necessary to acquire and assess and knowledge and skills prescribed. The module requires students to actively interact with the learning material, not just passively read the material alone. Students are asked to do various learning activities and obtain feedback on what they are doing. Some kind of evaluation strategies that exist in the module tells the student whether they achieve complete mastery of the material and what to do if they cannot achieve the required mastery (Dick \& Carey, 2001).

Lecturer is instrumental in conventional learning. To address a problem referring to less stimulating learning, a learning module should be developed. Development of learning modules as a form of learning materials can be more effective than conventional learning. Conventional teaching would reduce the ability of critical thinking, willingness, and study habits of learners. The effectiveness of this module also provides alternative action learning.

A learning module usually begins with a list of materials which will benefit their users or learners in order that they will be engaged in using it for their learning. The module is accompanied by a specific learning objective, so that students know the objectives to be achieved after participating in learning. The module is basically structured as follow: learning aims, learning outcomes, resources, learning and teaching strategies, assessment criteria and evaluation (Donelly and Fitzmaurice, n.d.). The module is also equipped with a pretest, thus 
causing students not to have difficulty in learning the material. Also, the module has feedbacks from the students' answers, so they can be corrected if an error occurs. The module provides enrichment materials as well, especially for fast learners.

The use of learning module is in line with constructivist learning strategies. Constructivism enables learners to construct their own understanding and knowledge of the world by experiencing things and reflecting on the experiences. This means that it deals with individuality, learner autonomy, and discovery learning. It has shifted emphasis, from teaching to learning, and it individualizes and contextualizes learner's knowledge construction and learning experiences. Furthermore, it makes learners take responsibility for their own learning as they are made to follow their own strategy of learning via the module.

With regard to Research Methodology course in higher education, the students faced difficulty in the course based on the following empirical studies. The results of research conducted by Wilson and Rosenthal (1992) showed that 58\% of the Finnish students and 21\% of the American students had difficulties in learning quantitative research methods. As many as $27 \%$ of the students in the U.S. experienced very high anxiety, $51 \%$ had moderate levels of anxiety, and the remaining $22 \%$ had a low level of anxiety. The students' problems in learning quantitative research methodology would directly influence their learning outcomes. Other studies by Murtonen and Lehtinen (2003) discovered that nearly $60 \%$ of the Finnish students were having problems in the course of statistical and quantitative research methodologies, the difficulties were due to poor teaching; whereas Semiawan (2003) explained that $30 \%$ the students in Indonesia were able to comprehend the reading materials and had difficulty answering questions that required a subjective form of reasoning.

Next, the results of the study by Mukhid, et al (2010) showed that $50 \%$ of the students had difficulties on the operational definition of variables, $100 \%$ of the students had difficulties on the moderator variable measurement and control, $80 \%$ had difficulties in designing of their study, and $50 \%$ of the students had difficulties in explaining the strengths and limitations of the study, explaining research implications and what would be done to improve the study.

Based on the results of these studies, it is recommended to apply constructivist learning strategy via modules that can solve the problem in the difficulties faced by students in learning the research methodology.

Thus constructive learning strategies can be used in learning research methodologies. Broers(2001, 2002)states that:

"The knowledge of facts, term and procedures should be integrated into a network of interrelation, i.e. conceptual understanding, before the solving of an abstract problem is possible".

This suggests that the research methodology is a subject matter that containsa lot of discussions about abstract concepts which are inter-related and challenging. It also requires deep understanding, which is not easy.

Lehtinen and Rui (1995) explains that learning problems in research methodology seems 
partly due to the complexity of the domain, i.e. knowledge of methodology that includes several properties that challenge students in which the subparts are very abstract and the relationship between the sub-parts abstract based on structural analogies, and the comprehension domains that require concrete procedures must be understood within the framework of a complete complex system.

The research methodology besides including abstract concept sand procedures that require real understanding which is noteasy, also requires skills in application, as cited by Hiebert and Lefevre (in Murtonenand Lethtinen, 2003):

The knowledge on research that students read from books and study in courses is not easy to understand or easily transmtted into practice. Methodological expertise requires vast amounts of conceptual knowledge ("knowing what"), although the research process in itself requires procedural knoledge ('knowing how').

Constructivism is a student-centered learning which is based on several principles as Simon, (n.d) has proposed, they are: (a) knowledge is constructed actively by the individual, (b) learning is an individual and social process, (c) learning is a process of self-regulation, (d) learning is an organizing process that allows one to make sense of their world, (e) cognition helps organizations of experiences in the world, not reality ontology and that truth as survival(variability), not the validity, (f) presenting the reality which represents an interpretation, $(\mathrm{g}$ ) learning is a social activity in the meaningful context, (h) languages抽ay an important role in learning and that thinking takes place in communication, and(i) motivation is a key component in learning.

Vembiarto (1990) has suggested eight characteristics of a learning module, they are: (a) a learning package that is 'self-instruction', (b) it recognizes the existence of individual differences, (c) it contains explicitly formulated objectives, (d) it deals with the existence of association, structure, and sequence of knowledge, (e) it uses a variety of instructional media, (f) there is active participation of students, (g) there is 'reinforcement 'directly to the student's response, and (8) there is evaluation of the mastery of the material.

According to Ruijter (1991), there are several advantages of a learning module, they are: (a) student motivation is high, because they have clear limits doing the given tasks and it suits their capabilities, (b) students immediately know the extent of his success and what shortcomings they have, (c) students achieve results within their capabilities, (4) load of the subjects will be more evenly divided throughout the semester, and (5) learning will be more efficient.

According to Wahjuni and Junaidi(2007), learning using module constitutes an independent study; whereas students area decisive factor in achieving learning success. Thus, it does not mean that professors contributelessor do not contribute at all. In the learningmodule, a lecturer is still required, namely as a facilitator.

Constructivist learning emphasizes the ability of students to solve real-life problems and practical problems (Richardson, 2003). According to Dewey and Vygosky (in Vrasidas, 2000), the interaction is one of the most important components of many learning experiences, both 
verbally and non-verbally, and consciously or unconsciously.

Design of learning using constructivist strategies with steps of 5E cycle consists of five steps adapted from Lorsbach learning(2002), namely(a) engage, (b) explore, (c) explain, (d) extend/elaborate, and(e) evaluate. Engage deals with the prior knowledge of learners that help them become involved in a new concept by reading, asking questions, conducting demonstrations, or performing some activities and developing curiosity and stimulating prior knowledge. Explore means that students work in collaborative teams to complete activities to get an idea, questioning and answering, designing and inquiry. Explain means that students can be explained by the presentation, sharing ideas with others, by way of reviewing and comparing their understanding to a more in-depth. Extend/elaborate means that students deepen their understanding on a concept by conducting additional activities. Evaluate is meant to encourage students to access on the understanding and ability to a concept and evaluating the expected goals.

\section{Method}

The development model used in the present study was adapted from the model ofthe development of Kemp(1985) and the development model of Dick \& Carey(2001). The results of the adaptation of both models produce measures to: (a) identify learning needs, (b) identify the characteristics of students, (c) identify the general purpose of learning, (d) conduct an analysis of learning, (e) formulate specific goals, (f) develop tests, (g) develop learning strategies, (h) develop and select instructional materials in the form of modules, (i) develop and implement evaluations, and (j) to revise the module.

The implementation procedures of the Research Methodology module were done through the following stages: (a) identifying learning needs as an attempt to locate and describing needs for a module on Research Methodology with constructivist learning strategies. To collect data, a questionnaire was used to identify the needs and there were two kinds, namely a questionnaire for students and a questionnaire for lecturers; (b) identifying the characteristics of students, the knowledge and skills of the students will be assessed before participating in learning activities with modules that will be developed; (c) identifying the general objectives derived from the list of objectives in the curriculum, the results of the analysis of learning needs and characteristics of students, and the results of a literature review; (d) analyzing general formulation of learning objectives and a review of the literature; (e) formulating specific goals in a form of special or specific statements of what students will be able to do when completing the specific learning; (e) developing the design and planning of learning strategies including measures of learning strategies; (e) developing a research methodology module prototype with constructivist learning strategies. Development is done on the basis of the previous steps, namely the identification of needs, identification of student characteristics, formulation of common goals, learning analysis, the formulation of specific objectives, results and current development plan developed learning strategies, and a review of the literature. This development results in the form of an outline of the content of the module that will be developed. 


\section{Results and Discussion}

A survey of 147 students of PGSD of University of PGRI Adi Buana was taken using a measuring instrument for analyzing the needs of students and lecturer, and analysis of student characteristics. The survey results were analyzed by using percentage can be described as follows:

\subsection{Preliminary Study}

The Research Methodology course is an independent study program given in semester 6 . The lecturers of Research Methodology courses are largely from the Department of Educational Technology and Elementary School Teacher Education (popularly known as Pendidikan Guru Sekolah Dasar orPGSD).

The learning method of Research Methodology which has been used, namely: (a) lectures, (b) questions and answers, (c) project, (d) training, and (e) discussion. Forms of learning materials used are in the bulk form of Power Point slides, handouts, materials in blogs/webs, and Research Methodology textbooks. No one has use a module as a learning material.

The learning of the Research Methodology needs for assistance as follows: (a) the provision of learning materials are equipped with practical examples, and (b) learning strategies that can change attitudes and increase students' learning motivation.

\subsection{Student Needs Analysis}

Based on the result of student need analysis, the course on Research Methodology in PGSD is a separate subject. This is consistent with the results of the preliminary observations conducted by the researcher. Furthermore, the results of the needs analysis questionnaire revealed that the position of the Research Methodology course in PGSD is as a separate course for 73 students $(49.7 \%)$ and the majority show that it was combined with Statistics course for 48 students (32.7\%). Portion of Research Methodology as a subject matter or part of the course, $70(50.3 \%)$ students responded that it was very large and 50 large $(34.0 \%)$. The materials of research methodology were taught by constructivist learning method for $(67.3 \%)$, and sometimes it used a method of constructivist learning (29.3\%). According to the students, Research Methodology material for their own purposes as prospective teachers of PGSD is considered very important $(82.3 \%)$. They were interested in Research Methodology lecture materials: some were very interested $(21.8 \%)$ and some were interested $(75.5 \%)$, because the students considered the subject important in completing the thesis requirement.

The form of the materials used in the course on Research Methodology included lectures using summary materials (handouts) made by the lecturers (53.7\%), college textbook compiled by the lecturers $(15.6 \%)$ and others $(23.8 \%)$. Most $(83 \%)$ of the Research Methodology material gave instructions to learn how to use such materials, the time needed to learn each subject, and the majority (17\%) had not provided the guidance to use them. The Research Methodology materials were available to be understood and applied in the development of research proposals and considered to be adequate $(63.3 \%)$.

The result also revealed that literature sources related to research methodology were detailed 
and fairly easy to learn (61.9\%). The students' attitude towards materials in the form of modules that specifically discusses the research methodology in the field of elementary education, whose content includes components ranging from instructions use, description of general and specific learning objectives, materials, exercises, and answer keys indicated that they strongly agreed (64.6\%), and agreed (33.3\%). attitude of students towards the developed module equipped with a CD that facilitated learning in Research Methodology study, showed that they strongly agreed (63.9\%) and agreed (34.0\%).

According to the students, the Research Methodology materials most needed at this time for a primary school teacher was knowledge in solving everyday problems with classroom action research(CAR) (39.5\%), and knowledge in solving the problems of the study $(25.9 \%)$.

\subsection{Lecturer Needs Analysis}

In general, the Research Methodology materials were mostly in forms of handouts, general books o nResearch Methodology and verbal explanations in class. The materials developed by the lecturers included description and examples of research proposals in general.

The quality of teaching materials used by the lecturers of Research Methodology was quite good, because it contained the components of learning objectives, material descriptions, and the exercises were not regarded as good learning materials, and the principles of learning development.

In general, the lecturer argued that it was necessary to develop a research methodology course materials qualify as good learning materials, and meet the principles of learning such as module development. It should be supplemented with $\mathrm{CD}$ that comes with learning that allowed students to learn research methodology with more ease.

The lecturers also suggested that the necessary components which should be included in the learning materials were as follows: instructions, prerequisites, learning objectives, introduction, material descriptions, summaries, exercises, feedback and follow-ups, and reading materials. Relating to the development of the module using constructivist strategies, the lecturers suggested that: (a) the module should also provide face-to-face meetings to verify the acquisition of knowledge, (b) the module should be equipped with various examples so that the students will notrepeat the same mistakes, and (c) the language used should be easily understood by the students.

\subsection{Student Characteristics Analysis}

Analysis of student knowledge or comprehension in the introductory materials to the sub-topics showed that: looking for the scientific truth was understood by $58.5 \%$ of the students, $52.4 \%$ understood the application of scientific method, $74.8 \%$ understood the nature of research, $81.0 \%$ understood functions of research, $66.7 \%$ understood research types, and $55.8 \%$ understood the relationship between scientific method with research. In relation to research problems, the result also showed that the background of the problem was understood by $95.2 \%$; whereas $91.8 \%$ of the students understood the formulation of the problem, research objectives, and hypotheses. $95.2 \%$ of the students understood the benefits of 
research, and $83 \%$ understood variables and operational definitions of variables. Concerning with the literature review, $57.1 \%$ of the students comprehended scientific arguments, $50.3 \%$ of the students did not comprehend steps in preparing literature review, 51\% lacked of understanding literature review selection criteria, and $55.8 \%$ of the students understood the sources literature review. Relating to the study design, $61.9 \%$ of the students did not understand that, $67.3 \%$ did not comprehend experimental study design, and $51.7 \%$ did not understand research subjects. In relation to the research instruments, $51.7 \%$ did not understand the instrument, $77.6 \%$ did not understand validity and reliability tests, and $83 \%$ did not understand preparation and testing of the validity and reliability tests. Concerning data collection and analysis techniques, $52.4 \%$ of the students lacked of understanding them. $64.6 \%$ did not understand all sorts of data analysis. $68 \%$ did not understand the stages of data analysis. The students lacking of understanding parametric constituted $74.1 \%$, and $74.8 \%$ did not understand non-parametric.

\subsection{Learning Analysis}

Analysis of learning Research Methodology showed that there were six topics in discussion, namely: (a) introduction, (b) research problems, (c) literature review, (d) research design and research subjects, (e) research instrument, and (f) data collection techniques and data analysis. The materials were divided into six Research Methodology standards of competence. Each of which was then specified into the learning objectives.

\subsection{Attitudes, Interests, and Student Motivation Analysis}

In the introduction to the sub-topic materials, it showed that $63.9 \%$ of the students did not really learn research methodology courses and $36.1 \%$ was less serious. $75.5 \%$ of the students were less happy about the research methodology course and $8.2 \%$ of them were delighted. $70.1 \%$ of the students considered the research methodology course not important; whereas .7\% of the students considered them important. $65.3 \%$ of the students were not trying to improve their way of learning to better understand the methodology of the study materials and $2.7 \%$ attempted. $68.7 \%$ of the students were less thrilled with the subjects that applied various problem solving activities such as research methodology and $11.6 \%$ were happy. $40.8 \%$ of the students did not think that it was a need for them to have knowledge of research methodology to complete the understanding of science and $2 \%$ of them felt the need. $6.8 \%$ of the students wished to follow the development of sciences including the study of research methodology that is being studied and $70.1 \%$ of them less wanted to follow the development. The students stated that they would be happier if the methodology of learning materials was in the form of a complete module (6.1\%), and 58.5\% who would not.

According to $9.5 \%$ of the students, learning research methodology would be more understandable and practical when using the constructivist learning model, whereas $68.7 \%$ of them did not quite agree. $8.2 \%$ of the students agreed that it would be more motivating if the learning materials of research methodologies using constructivism facilitate the student learning and $58.5 \%$ of them did not quite agree.

The results of the present study imply that the Research Methodology course in the study 
program benefits to support students' future thesis since it constitutes as a standalone course. In addition, the lecturers of Research Methodology courses were from the Graduate School of Education Technology and primary school teacher education(PGSD). This is reasonable because the materials have been taught by the skilled lecturers.

The results also indicate that the learning of Research Methodology had not used a learning module and the use of the developed learning module was more effective as it is consistent with Kemp's (1985) and Winkel 's (1991) statements (1985) that a learning module is suitable for a more individualized instruction. In addition, the learning module was developed based on the result of the student needs analysis. In using the module, the lecturers should serve as a facilitator of the students' learning. This is in line with what Wahjuni and Junaidi (2007) have suggested.

Furthermore, the module learning suits the principles of constructivist learning and student-centered learning as Simon (n.d) has stated. The materials used in the study imply that they have considered the required components of learning and developing learning materials.

Next, from the students' perspectives, the learning module is a necessity for them to develop their independence and performance. The development of the learning module was based on the student and lecturer needs, the student characteristics, the learning analysis, the learning strategies, and the literature review.

\section{Conclusion}

Based on the previous results, it can be concluded that: (a) Research Methodology is an independent course (b) the lecturers of the course had the qualifications, (c) the learning is still student-centered, (d) the learning sources include handouts, internet-based, and textbooks, (e) the learning is dominated by behaviorism and thus constructivist learning is necessary, (f) the learning module is needed, ( $\mathrm{g}$ ) CD should be provided to facilitate the learning, (h) Language used in the learning module should be more comprehensible, (i) A prototype of the desired product should be developed.

This study provides several suggestions: (a) Models of learning materials developed in the form of Research Methodology module should be equipped with learning CD and further research is necessary to develop materials with e-learning; (b)Lecturers should guide and prepare the students for ways of learning materials in the form of modules. 


\section{References}

Barrowes, P.A. (2000). A Student Centered Approach to Teaching General Biology That Reality Works: Lord's Constructivist Model Put to Test. The American Biology Teacher, 65(7), 491-501.

Broers, N.J. (2001). Analyzing Propositions Underlying the Theory of Statistics. Journal of Statistics Education, 9(3), (Online), diakses 26 Nvember 2010.

Broers, N.J. (2002). Selection and Use of Proportional Knowledge Statistical Problem Solving. Learning and Instruction, 12(3), 323-344. http://dx.doi.org/10.1016/S0959-4752(01)00025-1

Dick, W., Carey, L., \&Carey, J.O. (200). The Systematic Design of Intruction. Fifth Education New York: Longman.

Donelly, R., \& Fitzmaurice, M. (n.d) Designing Modules for Learning. Retrieved from http://www.aishe.org/readings/2005-1/donnelly-fitzmaurice-Designing_Modules_for_Le arning.html

Kemp, J.E. (1985). The Instuctional Design Process. New York: Harper \& Row.

Lehtinen, E., \& Rui, E. (1995). Computer-Supported Complex Learning: An Environment for Learning Experience Methods and Statistical Inference. Machine-Mediated Learning, 5(3\&4), 149-175.

Lorsbach, A. W. (2002). The Learning Cycle as a Tool for Planning Science Instruction. Retrieved from http://coe.ilstu.edu/scienceed/lorsbach/257lrcy.htm

Mahony, M. (2003). What is constructivism and why is it growing? Retrieved from http://www.constructivism123.com/What_Is/What_is_constructivism.htm

Mukhid, A. (2010). Laporan Penelitian Kolektif "Kemampuan Mahasiswa STAIN Pamekasan Dalam Memahami dan Aplikasi Metodologi Penelitian Kuantitatif Dalam Skripsi”. Pamekasan STAIN Press.

Murtonen, M., \& Lehtinen, E. (2003). Difficulties Experienced by Education and Sociology student in Quantitative Methods Courses. Studies in Higher Education, 28(2), 171-185. http://dx.doi.org/10.1080/0307507032000058064

Richardson, V. (2003). Constructivist Pedagogy. Teacher College Record, 105(9), 13-20. http://dx.doi.org/10.1046/j.1467-9620.2003.00303.x

Rufi'i. (2013). Pengaruh Strategi Pembelajaran Konstruktivistikdan Pengetahuan Awalterhadap Hasil Belajar Metodologi Penelitian. Proceeding. Surabaya: ISBN: 9789798559556 presented at the International Seminar, February $23^{\text {rd }}, 2013$.

Ruijter, K., \& Utomo, T. (1999). Peningkatan dan Pengembangan Pendidikan. Jakarta: PT Gramedia Pustaka Utama.

Semiawan, C. (2003). Pendidikan, Mutu Pendidikan, dan Peranan Guru. Dalam Gurudi 
Indonesia: Pendidikan, Pelatihan, dan Perjuangannya Sejak Jaman Kolonial Hingga Era Reformasi, Jakarta: Depdiknas Dirjen Dikdasmen, Dittendik.

Simon, D.S. (n.d) The Principles of Constructivism. Retrieved from http://web.rollins.edu/-gvaliante/couses/edu272_files/Constructivism,1

Vembriarto, St. (1990). Pengantar Pembelajaran Modul. Yogyakarta: Gunung Agung.

Vrasidas, C. (2000). Contructivism versus Objectivism: Implications for Interaction, Course Drsign, and Evaluation in Distance Education. Interational Journal of Education Telecommunications, 6(4), 339-362.

Wahjuni, S., \& Junaidi. (2007). Pengembangan Modul Pembelajaran Statistika Bidang Bahasa Berbantuan Komputer. Malang: FKIP Universitas Islam Malang.

Wilson, W.C., \& Rosenthal, B.S. (1992). Anxiety and Performance in an MSW Research and Statistics Course. Journal of Teaching in Social Work, 6(2), 75-85. http://dx.doi.org/10.1300/J067v06n02_07

Winkel. (1991). Psikologi Pengajaran. Jakarta: Penerbit PT Grasindo.

\section{Glossary}

PGSD: Pendidikan Guru Sekolah Dasar (Elementary School Teacher Education)

\section{Copyright Disclaimer}

Copyright for this article is retained by the author(s), with first publication rights granted to the journal.

This is an open-access article distributed under the terms and conditions of the Creative Commons Attribution license (http://creativecommons.org/licenses/by/3.0/). 